\title{
Abnormal Parathyroid Hormone Stimulation of 25-Hydroxyvitamin D-1 $\alpha$-Hydroxylase Activity in the Hypophosphatemic Mouse \\ Evidence for a Generalized Defect of Vitamin D Metabolism
}

Teresa Nesbitt, Marc K. Drezner, and Bruce Lobaugh

Departments of Medicine, Physiology, and Surgery, Duke University Medical Center, Durham, North Carolina 27710

\begin{abstract}
Abnormal regulation of vitamin $D$ metabolism is a feature of $X$ linked hypophosphatemic rickets in man and of the murine homologue of the disease in the hypophosphatemic (Hyp)-mouse. We previously reported that mutant mice have abnormally low renal 25-hydroxyvitamin D-1 $\alpha$-hydroxylase (1 $\alpha$-hydroxylase) activity for the prevailing degree of hypophosphatemia. To further characterize this defect, we examined whether Hyp-mouse renal $1 \alpha$-hydroxylase activity responds normally to other stimulatory and inhibitory controls of enzyme function. We studied stimulation by parathyroid hormone (PTH) using: (a) a calciumdeficient (0.02\% Ca) diet to raise endogenous PTH; or (b) 24-h continuous infusion of $0.25 \mathrm{IU} / \mathrm{h}$ bovine PTH via osmotic minipump. In both cases enzyme activity of identically treated normal mice increased to greater levels than those attained by Hypmice. The relative inability of PTH to stimulate $1 \alpha$-hydroxylase activity is not a function of the hypophosphatemia in the Hypmouse since PTH-infused, phosphate-depleted normal mice sustained a level of enzyme activity greater than that of normal and Hyp-mice. In further studies we investigated inhibition of enzyme activity by using: (a) a calcium-loaded (1.2\% Ca) diet to suppress endogenous PTH; or (b) 24-h continuous infusion of $0.2 \mathrm{ng} / \mathrm{h}$ 1,25-dihydroxyvitamin $\mathrm{D}_{3}\left(1,25(\mathrm{OH})_{2} \mathrm{D}_{3}\right)$. The $1 \alpha$-hydroxylase activity of normal and Hyp-mice was significantly reduced to similar absolute levels following maintenance on the calcium-loaded diet. Further, infusion of $1,25(\mathrm{OH})_{2} \mathrm{D}_{3}$ caused a comparable reduction of $1 \alpha$-hydroxylase activity in normal, Hyp-, and phosphate-depleted normal mice. These observations indicate that the inhibitory control of $1 \alpha$-hydroxylase by reduced levels of PTH or increased $1,25(\mathrm{OH})_{2} \mathrm{D}_{3}$ concentrations is intact in the mutants. However, the inability of PTH and hypophosphatemia to stimulate enzyme activity in a manner analogous to that in normal and phosphate-depleted mice indicates that a generalized defect of $1 \alpha$-hydroxylase regulation is manifest in Hyp-mice.
\end{abstract}

\section{Introduction}

$\mathrm{X}$-linked hypophosphatemia $(\mathrm{XLH})^{1}$ is the prototypic vitamin D-resistant rachitic disease, characterized by hypophosphatemia,

Portions of this work have appeared in abstract form, 1983. Clin. Res. 31:503 and 1984. Calcif. Tissue Int. 36:521.

Address reprint requests to Dr. Drezner, Box 3285, Duke University Medical Center, Durham, NC 22710.

Received for publication 17 December 1984 and in revised form 3 September 1985.

J. Clin. Invest.

(c) The American Society for Clinical Investigation, Inc.

$0021-9738 / 86 / 01 / 0181 / 07 \quad \$ 1.00$

Volume 77, January 1986, 181-187 impaired renal tubular reabsorption of phosphate, normocalcemia, growth retardation, and rickets and/or osteomalacia. Several studies have documented that abnormal regulation of vitamin $\mathrm{D}$ metabolism is also a component of the disorder in man $(1,2)$ and in the murine homologue, the hypophosphatemic (Hyp) mouse (3-6). The paradoxical occurrence of hypophosphatemia and normal serum 1,25-dihydroxyvitamin D $\left(1,25(\mathrm{OH})_{2} \mathrm{D}\right)$ concentrations marks this defect in affected humans and mutant mice. Recently, data have emerged which suggest that the aberrant vitamin D metabolism in Hyp-mice is due to inappropriately low renal 25 -hydroxyvitamin $\mathrm{D}-1 \alpha$-hydroxylase ( $1 \alpha$-hydroxylase) activity in the setting of chronic hypophosphatemia (4). In addition, several investigators have provided evidence that this abnormality is indicative of a more generalized defect $(6,7)$. However, our understanding of the effects of specific factors on the regulation of enzyme activity in vivo remains incomplete. Thus, in the present study we examined whether the renal $1 \alpha$-hydroxylase of Hyp-mice responds normally to several principal stimulatory (calcium depletion, parathyroid hormone [PTH]) and inhibitory controls (calcitriol, calcium loading) of function known to be operant in unaffected littermates. We assessed the renal $1 \alpha$-hydroxylase in Hyp-mice and age-matched normals using our sensitive in vitro assay of murine enzyme activity (8).

\section{Methods}

\section{Animals}

Normal C57BL/6J mice were mated with $\mathrm{C} 57 \mathrm{BL} / 6 \mathrm{~J}$ heterozygous female Hyp-mice as previously described (9). Male and female weanling Hypmice obtained from the resultant litters were identified (9) and selected for study at $4 \mathbf{w k}$ of age. Hyp-mice of both sexes were used in our investigation since previous studies have indicated that the biochemical expression of the Hyp-mutation is present to an almost identical extent in females, despite the X-linked dominance of the disorder (10). An equal number of male and female normal littermates were also chosen. All animals received an appropriate diet (as described below) and deionized water ad lib. until killed.

\section{Experimental protocols}

STIMULATION OF RENAL $1 \alpha$-HYDROXYLASE ACTIVITY IN NORMAL AND HYP-MICE. Dietary calcium depletion. In our initial investigations we examined the effect of PTH on renal $1 \alpha$-hydroxylase activity by inducing dietary calcium depletion in age-matched normal and Hypmice. Identical numbers of male and female mice were allocated to two groups for each animal model. Animals were bled via retro-orbital sinus puncture before dietary treatment (at age $4 \mathrm{wk}$ ) for determination of plasma calcium and inorganic phosphorus concentrations. Control nor-

1. Abbreviations used in this paper: $1,25(\mathrm{OH})_{2} \mathrm{D}, 1,25$-dihydroxyvitamin $\mathrm{D} ; 1,25(\mathrm{OH})_{2} \mathrm{D}_{3}, 1,25$-dihydroxyvitamin $\mathrm{D}_{3} ; 25(\mathrm{OH}) \mathrm{D}_{3}$, 25-hydroxyvitamin $\mathrm{D}_{3} ; 1 \alpha$-hydroxylase, 25 -hydroxyvitamin $\mathrm{D}$-1 $\alpha$-hydroxylase; Hyp, hypophosphatemic; P-depleted, phosphate depleted; PTH, parathyroid hormone; XLH, X-linked hypophosphatemic rickets/osteomalacia. 
mal and Hyp-mice were fed a standard commercial diet containing $0.6 \%$ of both calcium and inorganic phosphorus (Teklad Company, Madison, WI), while calcium-depleted members of each group received an otherwise identical diet containing $0.02 \%$ calcium. Animals were maintained on these rations until exsanguination at $8 \mathrm{wk}$ of age. At this time mice were killed and kidneys were removed for measurement of renal $1 \alpha$-hydroxylase activity.

Continuous infusion of $P T H$. In subsequent studies we administered PTH directly so that the uniformity of the applied stimulus could be more carefully controlled. We employed surgically implantable Alzet osmotic minipumps (model 2001; Alza Corp., Palo Alto, CA) for continuous subcutaneous infusion of PTH into normal and Hyp-mice fed the standard control diet and into phosphate (P)-depleted normal mice which received an otherwise identical ration with $0.02 \%$ inorganic phosphorus for $4 \mathrm{wk}$. Bovine parathyroid extract ( $138 \mathrm{IU} / \mathrm{mg}$, Sigma Chemical Co., St. Louis, $\mathrm{MO})$ was dissolved in physiological saline $(0.9 \% \mathrm{NaCl})$ containing $20 \mathrm{mg} / \mathrm{ml}$ cysteine hydrochloride. Minipumps were filled with the PTH solution $(0.25 \mathrm{IU} / \mu \mathrm{l})$ and immersed in saline for $24 \mathrm{~h}$ before implantation in order to allow for equilibration of pump-flow rate. After sodium pentobarbital anesthesia $(65 \mathrm{mg} / \mathrm{kg}$, i.p.), the minipumps were implanted subcutaneously in the normal, Hyp-, and P-depleted normal mice through a small skin incision in the dorsal lumbar region. The incision was closed with a wound clip. Sham mice were implanted with a segment of polyethylene tubing approximately the size of the Alzet minipump. After $24 \mathrm{~h}$ the mice were exsanguinated, dispatched, and the kidneys excised for measurement of $1 \alpha$-hydroxylase activity. Plasma calcium, inorganic phosphorus, and immunoreactive PTH were determined for all groups.

The time course and dose dependency of $1 \alpha$-hydroxylase response to PTH infusion were also evaluated in the normal and Hyp-mouse models. In the former experiment, age- and sex-matched normal and Hyp-mice were assigned to either pump-infused or sham-operated groups. Infused mice received a dose of $0.25 \mathrm{IU} / \mathrm{h} \mathrm{PTH}$, and pumps or tubing segments were implanted $6,12,18,24,36$, or $48 \mathrm{~h}$ before exsanguination. Dose responses to PTH were examined in normal and Hyp-mice implanted with pumps infusing $0.025,0.05,0.1,0.25$, or $0.50 \mathrm{IU} / \mathrm{h}$ PTH $24 \mathrm{~h}$ before study.

INHIBITION OF RENAL $1 \alpha$-HYDROXYLASE ACTIVITY IN NORMAL AND HYP-MICE. Dietary calcium loading. To further evaluate the importance of PTH in the modulation of $1 \alpha$-hydroxylase activity, identical numbers of male and female normal and Hyp-mice were allocated to two groups for each animal model. Animals were bled via retro-orbital sinus puncture before dietary treatment (at age $4 \mathrm{wk}$ ) for determination of plasma calcium and inorganic phosphorus concentrations. Control normal and Hyp-mice were fed a standard commercial diet containing $0.6 \%$ of both calcium and inorganic phosphorus (Teklad Co.), while calcium-loaded members of each group received an otherwise identical diet containing $1.2 \%$ calcium. Animals were maintained on these rations until exsanguination at 8 wk of age. At this time mice were killed and kidneys were removed for measurement of renal $1 \alpha$-hydroxylase activity.

Continuous infusion of 1,25-dihydroxyvitamin $D_{3}\left(1,25(\mathrm{OH})_{2} \mathrm{D}_{3}\right)$. In another series of experiments the effect of continuously administered $1,25(\mathrm{OH})_{2} \mathrm{D}_{3}$ on renal $1 \alpha$-hydroxylase activity was examined in normal, P-depleted normal, and Hyp-mice. The Alzet osmotic minipump was employed for infusion of the hormone $(0.2 \mathrm{ng} / \mathrm{h})$ with propylene glycol used as the carrier solvent. Infusion of $1,25(\mathrm{OH})_{2} \mathrm{D}_{3}$ was maintained for $48 \mathrm{~h}(1 \mu \mathrm{l} / \mathrm{h})$ after which the mice were bled for plasma biochemical determinations and kidneys removed for assay of $1 \alpha$-hydroxylase activity.

\section{Analytical methodology}

IN VITRO ASSAY OF MURINE $1 \alpha$-HYDROXYLASE ACTIVITY. We measured the maximum velocity of $1 \alpha$-hydroxylase activity in kidney homogenates by our previously described method (8). The assay utilizes: (a) sufficient nonradioactive 25-hydroxyvitamin $\mathrm{D}_{3}\left(25(\mathrm{OH}) \mathrm{D}_{3}\right)$ to maintain an optimum concentration for $1 \alpha$-hydroxylation (8), while saturating the inhibitory factor present in mammalian renal homogenates (11-18); (b) a sample purification scheme consisting of chloroform/ methanol (1:2) extraction of kidney homogenates, Sephadex LH-20 chromatography of lipid extract, and high performance liquid chromatography (hexane/2-propanol, 90:10) of purified lipid extract on a microporasil column (Waters Assoc., Millipore Corp., Milford, MA) to achieve resolution of the $1,25(\mathrm{OH})_{2} \mathrm{D}_{3}$ produced in vitro; and $(c)$ a competitive protein binding assay $(8,19)$ for quantifying the hormone.

PLASMA BIOCHEMICAL DETERMINATIONS. Plasma measurements were performed using previously established methods. Calcium was analyzed using an atomic absorption spectrophotometer (model 272, Perkin Elmer Corp., Instrument Div., Norwalk, CT), and inorganic phosphorus determined by a colorimetric technique (20). PTH was quantified by a commercially available carboxyterminal specific radioimmunoassay kit (Diagnostic Systems Laboratories, Webster, TX). The limit of detection for the assay is $0.05 \mathrm{ng} / \mathrm{ml}$ and the interassay coefficient of variation $8.4 \%$.

\section{Statistical methods}

Data are expressed as mean \pm SE. We evaluated the data statistically using paired $t$-testing, two-way analysis of variance (with appropriate $a$ posteriori multiple range comparison procedures), and regression analysis (21). The adequacy of all statistical models was examined using residual plots, Bartlett's test for homogeneity of error variance, and cumulative normality probability plots.

\section{Materials}

J. Alan Campbell, Upjohn Co., Kalamazoo, MI, generously donated authentic $25(\mathrm{OH}) \mathrm{D}_{3}$ and Dr. Milan Uskokovic, Hoffman La Roche, Nutley, $\mathrm{NJ}$, kindly provided authentic $1,25(\mathrm{OH})_{2} \mathrm{D}_{3}$ for our studies. We purchased $\left[{ }^{3} \mathrm{H}\right] 1,25(\mathrm{OH})_{2} \mathrm{D}_{3}(92 \mathrm{Ci} / \mathrm{mmol})$ from Amersham Searle Corp., Arlington Heights, IL.

\section{Results}

\section{Stimulation of renal $1 \alpha$-hydroxylase activity in normal and Hyp-mice}

Dietary calcium depletion. Plasma calcium concentrations in normal mice after $4 \mathrm{wk}$ on the calcium-deficient diet did not differ significantly from those of normal mice on a control diet $(8.9 \pm 0.16 ; 9.2 \pm 0.29 \mathrm{mg} / \mathrm{dl}$, respectively). However, normal mice fed the calcium-deficient diet manifested a $150 \%$ enhancement of renal $1 \alpha$-hydroxylase activity compared to those on the control ration (Fig. 1). In contrast, a significant fall in plasma calcium

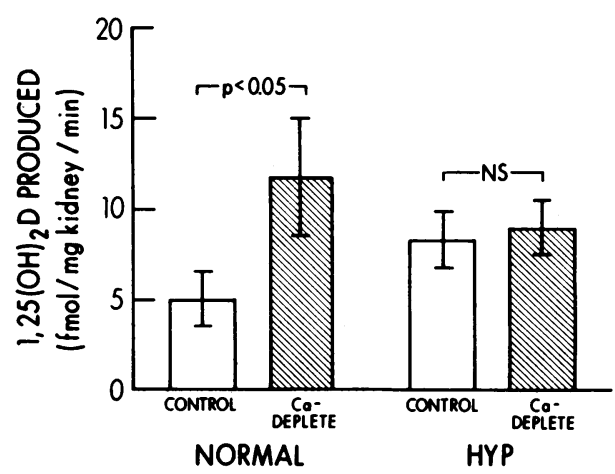

Figure 1. 25-hydroxyvitamin D-1 $\alpha$-hydroxylase activity of normal and Hyp-mice after maintenance for $4 \mathrm{wk}$ on either a standard $(0.6 \%$ $\mathrm{Ca})$ or calcium-depleted $(0.02 \% \mathrm{Ca})$ diet. Each bar represents the mean $\pm \mathrm{SE}$ of determinations obtained from three separate experiments $(n=3)$. In each experiment individual reaction vessels contained 100 $\mathrm{mg}$ of kidney cortex, $\sim 1 / 4$ of the pooled kidney homogenate from three to five mice in each group. All samples were incubated at $37^{\circ} \mathrm{C}$ with $80 \mu \mathrm{M} 25(\mathrm{OH}) \mathrm{D}_{3}$ provided as substrate. Data were analyzed by two-way analysis of variance and Tukey's multiple range comparison test. 


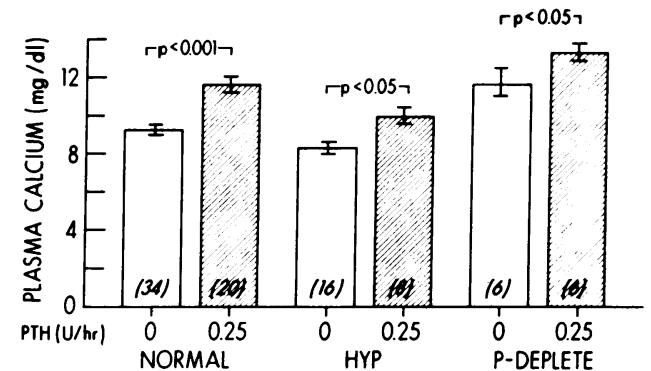

Figure 2. Plasma calcium concentration of normal, Hyp-, and P-depleted mice before and $24 \mathrm{~h}$ after continuous subcutaneous administration of $0.25 \mathrm{IU} / \mathrm{h}$ bovine PTH. In each mouse model the significance of the difference between pre- and post-infusion plasma calcium concentrations was assessed by the paired Student's $t$ test. Each bar represents the mean $\pm \mathrm{SE}$ of the number of determinations indicated.

was observed in Hyp-mouse littermates on the calcium-deficient diet relative to those on the control ration $(8.0 \pm 0.26$ vs. $8.5 \pm 0.02$, respectively, $P<0.05$ ). Despite the presence of this stimulus, enzyme activity in Hyp-mice was not increased above basal levels (Fig. 1).

Continuous infusion of PTH. Administration of PTH $(0.25$ IU/h, subcutaneously) to normal, P-depleted, and Hyp-mice resulted in significant increments of similar magnitude in the plasma calcium concentrations after $24 \mathrm{~h}$ (Fig. 2). Comparable increases in $\mathrm{COOH}$-terminal immunoreactive PTH were also observed (Fig. 3). In contrast, normal mice responded to the standard PTH stimulus with a 6.6-fold enhancement of renal $1 \alpha$-hydroxylase activity, while Hyp-mice exhibited a significantly lesser 2.2-fold enhancement (Fig. 4). The relative inability of PTH to stimulate enzyme activity in the mutant mouse is apparently not a function of the hypophosphatemia present in this animal model, since phosphate depleted normals, which manifest similar levels of plasma phosphorus, sustained a 5.0-fold increase in $1 \alpha$-hydroxylase activity, a level significantly greater than that of Hyp-mice (Fig. 4).

The difference in the $1 \alpha$-hydroxylase activity expressed in normal and Hyp-mouse kidneys following $24 \mathrm{~h}$ of PTH infusion

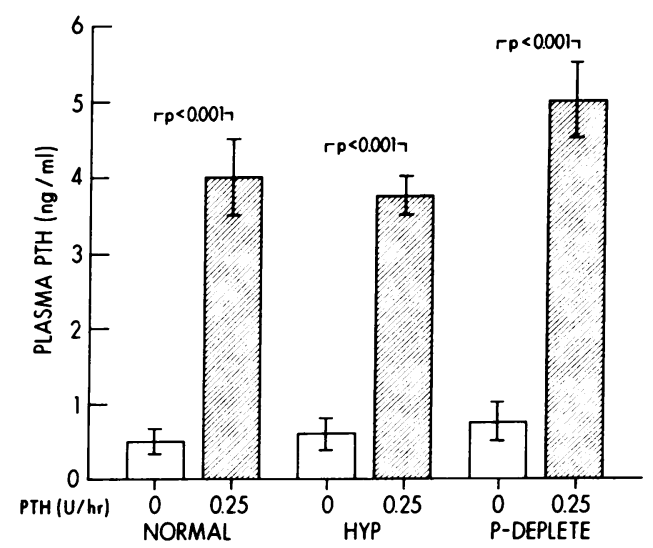

Figure 3. Plasma PTH concentration of normal, Hyp-, and P-depleted mice before and $24 \mathrm{~h}$ after continuous subcutaneous administration of $0.25 \mathrm{IU} / \mathrm{h}$ bovine PTH. Each bar represents the mean \pm SE of five individual determinations. In each mouse model the significance of the difference between the pre- and post-infusion plasma PTH concentration was assessed by the paired Student's $t$ test.

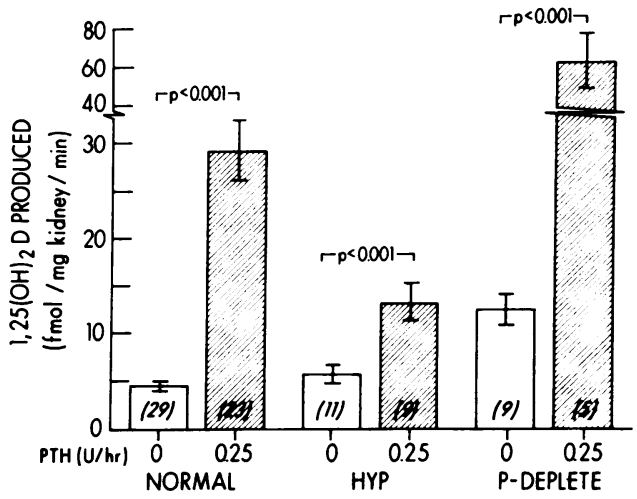

Figure 4. 25-hydroxyvitamin D-1 $\alpha$-hydroxylase activity of normal, Hyp-, and P-depleted mice following continuous subcutaneous administration of $0.25 \mathrm{IU} / \mathrm{h}$ bovine PTH. Each bar represents the mean $\pm \mathrm{SE}$ of determinations obtained from the number of experiments indicated in parentheses. In each experiment individual reaction vessels contained $100 \mathrm{mg}$ of kidney, $\sim 1 / 4$ of the pooled homogenate from three to five mice in each group. All samples were incubated at $37^{\circ} \mathrm{C}$ with 80 $\mu \mathrm{M} 25(\mathrm{OH}) \mathrm{D}_{3}$ provided as substrate. Data were analyzed by two-way analysis of variance and Tukey's multiple range comparison test.

was not a result of an altered time course of PTH stimulation in affected animals. Enzyme activity in response to $0.25 \mathrm{IU} / \mathrm{h}$ PTH at various times ranging from 0 to $72 \mathrm{~h}$ of infusion displayed a linear increase through $24 \mathrm{~h}$ in both groups (Fig. 5). However, while $1 \alpha$-hydroxylase activity reached a maximum level after $24 \mathrm{~h}$ of infusion in both groups, the slope of the enzymatic response in the Hyp-mice was 4.3-fold lesser than that observed in normals $(P<0.01)$.

Further, the Hyp-mice sustained no phase shift in response to PTH stimulation either to the right or left of that demonstrated in normal animals. Dose-response studies over $24 \mathrm{~h}$ revealed that normal mice sustained a linear increase of $1 \alpha$-hydroxylase activity in response to graduated amounts $(0-0.5 \mathrm{IU} / \mathrm{h})$ of administered PTH, while identical treatment in mutants resulted in a curvilinear increase of enzyme activity to a plateau achieved at $0.1 \mathrm{IU} / \mathrm{h}$ (Fig. 6).

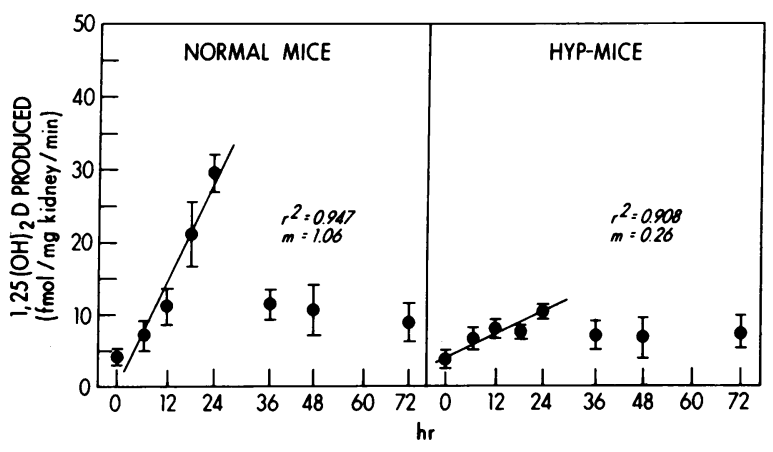

Figure 5. Effect of infusion time on $1,25(\mathrm{OH})_{2} \mathrm{D}_{3}$ produced by normal and Hyp-mouse kidney homogenates after stimulation with $0.25 \mathrm{IU} / \mathrm{h}$ of bovine PTH. Each point shown represents the mean \pm SE of determinations obtained from three experiments. In each experiment individual reaction vessels contained $100 \mathrm{mg}$ of kidney, aliquots of the pooled homogenate from mice of each group. All flasks were incubated at $37^{\circ} \mathrm{C}$ with $80 \mu \mathrm{M} 25(\mathrm{OH}) \mathrm{D}_{3}$ provided as substrate. Regression models were used to fit the data obtained. 


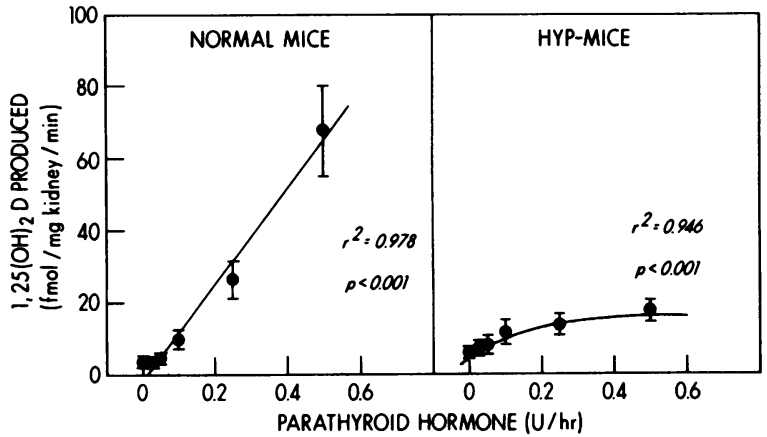

Figure 6. Effect of PTH dose on $1,25(\mathrm{OH})_{2} \mathrm{D}_{3}$ produced by normal and Hyp-mouse renal homogenates after $24 \mathrm{~h}$ of infusion. Each point shown represents the mean \pm SE of determinations obtained from four separate experiments $(n=4)$. In each experiment, individual reaction vessels contained $100 \mathrm{mg}$ of kidney, aliquots of the pooled homogenate from mice of each group. All samples were incubated at $37^{\circ} \mathrm{C}$ with $80 \mu \mathrm{M} 25(\mathrm{OH}) \mathrm{D}_{3}$ provided as substrate. Regression models were used to fit the data obtained.

\section{Inhibition of renal $1 \alpha$-hydroxylase activity in normal and Hyp-mice}

Dietary calcium loading. Plasma calcium concentrations in the normal mice after $4 \mathrm{wk}$ on the high calcium diet did not differ significantly from those of normal mice on the control diet $(8.7 \pm 0.35 ; 9.5 \pm 0.56 \mathrm{mg} / \mathrm{dl}$, respectively). Similarly, no significant increment in plasma calcium was observed in the mutants. However, $1 \alpha$-hydroxylase activity of both normal and Hyp-mice fed the high calcium diet fell to similar levels, each significantly reduced from those obtained in their littermates maintained on the control diet (Fig. 7).

Continuous infusion of $1,25(\mathrm{OH})_{2} \mathrm{D}_{3}$. Administration of $1,25(\mathrm{OH})_{2} \mathrm{D}$ by Alzet minipump did not significantly alter the serum calcium concentration in normal $(9.5 \pm 0.5 \mathrm{mg} / \mathrm{dl}$ vs. $11.1 \pm 0.60)$, Hyp- $(8.6 \pm 0.04 \mathrm{mg} / \mathrm{dl}$ vs. $8.8 \pm 0.20)$, or P-depleted mice $(13.0 \pm 0.27 \mathrm{mg} / \mathrm{dl}$ vs. $12.47 \pm 0.60)$. In contrast, infusion of $0.2 \mathrm{ng} / \mathrm{h} 1,25(\mathrm{OH})_{2} \mathrm{D}_{3}$ caused a comparable reduction of $1 \alpha-$ hydroxylase activity in normal, Hyp-, and P-depleted mice (Fig. 8). However, while the magnitude of the reduction was similar in the renal homogenates of each animal model, the absolute level of enzyme activity maintained was significantly greater in P-depleted normal mouse kidney than that in mutant kidney. These data provide further evidence that the $1 \alpha$-hydroxylasestimulating component associated with hypophosphatemia may be absent or reduced in the Hyp-mouse model of human XLH.

\section{Discussion}

A role of abnormal vitamin $D$ metabolism in the pathogenesis and phenotypic expression of XLH has long been suspected, but until recently studies aimed at exploring this hypothesis were indirect and limited to measurement of circulating vitamin D metabolites under various conditions in normal and affected subjects $(1,19,22,23)$. With the advent of current technology permitting direct assay of mammalian renal 25-hydroxyvitamin D hydroxylases $(8,24-26)$, the existence of a defect in the regulation of renal $1,25(\mathrm{OH})_{2} \mathrm{D}_{3}$ synthesis has been confirmed in the Hyp-mouse animal model of human XLH (4), and independent efforts have begun toward further characterization of this abnormality.

Lobaugh and Drezner (4) used methodology described earlier (8) to establish a disparity in the responses of normal and Hypmice to hypophosphatemia. However, it was unclear whether the defect recognized represents an altered enzyme response to phosphate depletion alone or is indicative of a generalized regulatory anomaly. Thus, we undertook the work documented in this report to study the modulation of normal and Hyp-mouse renal $1 \alpha$-hydroxylase by the other major effector of enzyme activity known in animal species, PTH (27-29). Initially we investigated the stimulatory effect of PTH on enzyme function by inducing dietary calcium depletion and thereby increasing en-

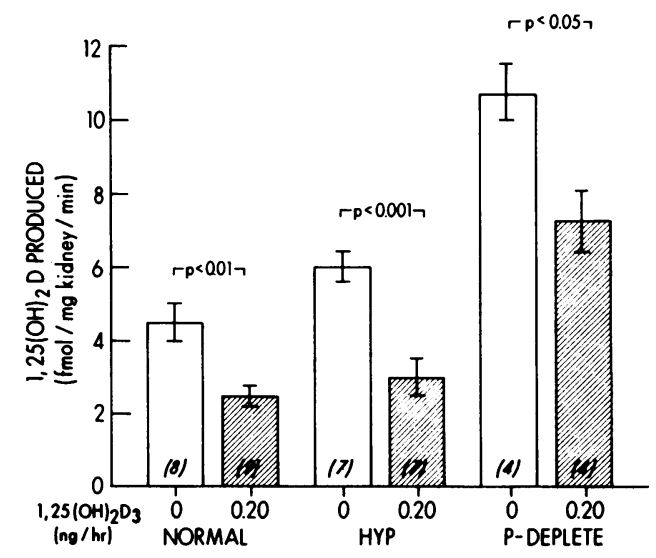

Figure 8. 25-hydroxyvitamin D-1 $\alpha$-hydroxylase activity in normal, Hyp-, and P-depleted mice following continuous subcutaneous infusion of $0.2 \mathrm{ng} / \mathrm{h} 1,25(\mathrm{OH})_{2} \mathrm{D}_{3}$ for $48 \mathrm{~h}$. Each bar represents the mean $\pm \mathrm{SE}$ of determinations obtained from the number of experiments indicated in parentheses. In each experiment individual reaction vessels contained $100 \mathrm{mg}$ of kidney, $\sim 1 / 4$ of the pooled homogenate from three to five mice in each group. All samples were incubated at $37^{\circ} \mathrm{C}$ with $80 \mu \mathrm{M} 25(\mathrm{OH}) \mathrm{D}_{3}$ provided as substrate. Data were analyzed by two-way analysis of variance and Tukey's multiple range comparison test. 
dogenous PTH secretion. Our results demonstrate that chronic consumption of a calcium-deficient diet does not significantly enhance enzyme activity in Hyp-mice as it does in normal animals, despite a significant reduction of plasma calcium concentration in the mutants (Fig. 1). While these data taken together with our earlier results (4) suggest that Hyp-mice manifest a generalized defect of renal $1 \alpha$-hydroxylase regulation, we were not satisfied that dietary manipulation achieved a uniform increment of PTH and thereby an equivalent stimulus. In her study of the mechanism of abnormal renal $1 \alpha$-hydroxylase activity in Hyp-mouse mitochondrial preparations, Tenenhouse (7) measured PTH concentrations of normal and mutant mice fed a calcium- and vitamin D-deficient diet in an attempt to verify the equipotence of the dietary stimulus in both groups. However, the poor cross-reactivity of murine PTH with most heterologous antibodies and the lack of adequate documentation regarding characterization of those antisera that permit detection of measurable levels of murine hormone continue to hinder definitive measurement and interpretation of endogenous immunoreactive PTH concentrations in mice. These observations are supported by: (a) our inability to measure murine PTHemploying antibodies with antigenic specificities to the mid-region of the human and/or bovine hormone; $(b)$ the conflicting reports of normal $(30,31)$ and elevated (32) levels of PTH in Hyp-mice; and ( $c$ ) our demonstration of elevated bioactive PTH concentrations in Hyp-mice despite normal immunoreactive PTH levels determined by two separate assays (33). Thus we chose a surgically implantable continuous infusion osmotic pump to administer a predetermined dose of immuno- and bioactive bovine PTH subcutaneously to mice maintained on a vitamin D-replete standard diet and measured the presence of hormone with a radioassay specifically characterized and validated for bovine PTH. The Alzet minipump has been successfully used by a number of investigators for long-term delivery of PTH (34-36) in a variety of animal species. The similar increments observed in each animal model of both plasma calcium (Fig. 2) and immunoreactive PTH (Fig. 3) confirm that a uniform stimulus was indeed applied to the groups of mice we studied. Following $24 \mathrm{~h}$ of bovine PTH infusion $(0.25 \mathrm{IU} / \mathrm{h})$, renal homogenates from normal mice exhibited an increase in enzyme activity far above that seen in Hyp-mouse kidney (Fig. 4).

Administration of PTH by minipump has also permitted examination of the time course and dose dependency of the response to PTH infusion in normal and Hyp-mice, which offers further insight into the apparent defect in enzyme regulation present in the mutants. In normal kidney the capacity for PTH to enhance $1 \alpha$-hydroxylase activity was not exceeded throughout the range of dosages tested. Conversely, infusion of hormone at concentrations above $0.1 \mathrm{IU} / \mathrm{h}$ caused no further increase in enzyme activity in Hyp-kidney (Fig. 6). Moreover, the absolute level of activity achieved by the maximal dose in the Hyp-mouse is significantly less than that of normals.

In the normal mouse, $1 \alpha$-hydroxylase activity reaches a peak by $24 \mathrm{~h}$ of infusion of $0.25 \mathrm{IU} / \mathrm{h}$ PTH and declines thereafter (Fig. 5). This loss of responsiveness may be a function of several mechanisms, including down regulation of the PTH receptor and product inhibition of the enzyme by increased levels of $1,25(\mathrm{OH})_{2} \mathrm{D}$. In the Hyp-mouse, however, no such reduction in responsiveness occurs throughout the time course monitored and the maximum level of enzyme activity attained is significantly less than that in normals after $24 \mathrm{~h}$ of continuous infusion (Fig. 5).
The observation that constant infusion of $1,25(\mathrm{OH})_{2} \mathrm{D}_{3}$ inhibits $1 \alpha$-hydroxylase activity in normal, P-depleted normal, and Hyp-mouse kidney (Fig. 8) is revealing in several respects. First, it suggests that the negative feedback component of the hormone on its own production is intact in the Hyp-mouse model. Indeed, the absence of a significant change of the serum calcium concentration in response to $1,25(\mathrm{OH})_{2} \mathrm{D}_{3}$, in each of the animal models reinforces the possibility that the effects of the hormone represent feedback inhibition. Secondly, the ratio of enzyme activities in the three animal models after $1,25(\mathrm{OH})_{2} \mathrm{D}_{3}$ infusion is virtually identical to that which we have previously described for the same groups under basal conditions. The increase in $1 \alpha-$ hydroxylase which is maintained in the $\mathrm{P}$-depleted mouse relative to its Hyp-counterpart reemphasizes the notion that a stimulatory component is present in these animals which is apparently not operant in mutant mice. Since phosphate depletion is associated with hypercalcemia and, presumably, reduced secretion of PTH in normal animals, it is unlikely that PTH is playing a role in sustaining the elevated enzyme activity. Rather, given our current knowledge of vitamin D metabolism, it would seem more logical to assume that the noninhibited component of enzyme activity present in the P-depleted normals, but absent in Hyp-mice, represents the independent capacity of renal $1 \alpha$-hydroxylase to respond to hypophosphatemia. In further support of this hypothesis, we observed that enzyme activities of calcium-loaded normal and Hyp-mice fall to identical levels (Fig. 7) even though the relative hypophosphatemia in mutants relative to normal animals is maintained.

Other investigators have employed several approaches to study aspects of the regulation of renal $1 \alpha$-hydroxylase activity in the Hyp-mouse model using different assay methodologies. Fukase et al. (6) employed primary culture of normal and Hypmouse renal cortical cells to study stimulation and/or inhibition of enzyme activity under a variety of conditions. In contrast to the enzyme enhancement present in cultures of normal cells in response to calcium-depleted or calcitonin-supplemented medium, they observed unresponsiveness in Hyp-mouse renal cortical cell cultures. While these findings provide potentially useful information for understanding innate enzyme defects and direct actions of single effectors on the specific target cell, use of a culture system introduces several difficulties hindering extrapolation of these results to the disease state in the intact organism. Serum-free in vitro culture removes the enzyme from its complete natural environment and potentially interrelated effectors, and may impose confounding difficulties of interpretation due to either cellular dedifferentiation or loss of memory of the in vivo setting. Indeed, alterations of this kind may account for the reported normal PTH-responsiveness observed in the Hypmouse renal cells, which is discrepant with our observations. Thus, while use of suitable culture systems complements our knowledge concerning $1 \alpha$-hydroxylase itself, studies of enzyme regulation which better reflect in vivo conditions are necessary for gaining a full understanding of the nature of the regulatory abnormality in mutant mice.

Tenenhouse (7) studied the mechanism of abnormal $1 \alpha$-hydroxylase regulation in vitamin D-deficient, calcium-deficient Hyp-mice using the purified renal mitochondrial method of Vieth and Fraser (25) to measure enzyme activity. Hyp-mice maintained for $6 \mathrm{wk}$ on a rachitogenic diet exhibited significantly lesser enzyme activity than normal mice fed the same diet. However, use of a vitamin D- and calcium-deficient ration irreconciliably confounded extension of those findings to Hyp- 
mice maintained under basal conditions, since the potentially differential effects of simultaneous vitamin $\mathbf{D}$ deficiency, calcium deficiency, and parathyroid hormone excess could not be separated. As a result, our understanding of the effects of these factors on the modulation of $1 \alpha$-hydroxylase activity in the mutant mouse remained incomplete.

In contrast to these studies, which suggest a generalized impairment of enzyme production, Meyer et al. (10) demonstrated an appropriate increase of plasma $1,25(\mathrm{OH})_{2} \mathrm{D}$ in calcium-deprived Hyp-mice. While this may represent a compensatory alteration of $1,25(\mathrm{OH})_{2} \mathrm{D}$ degradation, no data exist to substantiate this possibility. Thus, either $(a)$ differences in experimental protocol regarding age of mice or duration of experimental manipulation account for the discrepancy, or $(b)$ the concentration of $1,25(\mathrm{OH})_{2} \mathrm{D}$ in plasma is not a reliable estimate of $1 \alpha$-hydroxylase activity.

In any case, we believe that our measurements of renal $1 \alpha$ hydroxylase provide appropriate data addressing abnormalities of vitamin $\mathrm{D}$ metabolism in its natural in vivo setting. While our assay for assessment of $1 \alpha$-hydroxylase has many of the technical advantages of an in vitro system, the method which we employed permits examination of the stimulatory and/or inhibitory components in vivo where secondary or tertiary effects of importance for the complete phenotypic expression of the disease in intact organisms are ultimately reflected. Further, assay sensitivity is at least as high as that reported in other systems. We recognize of course that our measurements reflect maximum velocity of enzyme activity and do not necessarily reflect abnormalities which manifest when substrate concentration is physiologic. Nevertheless we believe our studies represent a rational, valid approach to examining the questions raised.

The present findings together with the results of our earlier report (4), support the hypothesis that renal $1 \alpha$-hydroxylase activity in the Hyp-mouse model of human XLH is abnormally regulated by both major known modulators of enzyme function, PTH and hypophosphatemia. We suspect that affected humans manifest a similar derangement.

\section{Acknowledgments}

We thank Ms. Janice Almond for her excellent assistance.

This work was supported by grants 2R01-AM-27032, 5T32-AM07012, and 5101-Ca-11265 from the National Institutes of Health and 1-852 from the March of Dimes Birth Defects Foundation. Dr. Lobaugh is a recipient of a National Institutes of Health Individual Research Service Award AM-06-998.

\section{References}

1. Lyles, K. W., and M. K. Drezner. 1982. Parathyroid hormone effects on serum 1,25-dihydroxyvitamin $D$ levels in patients with $X$ linked hypophosphatemic rickets: evidence for abnormal 25-hydroxyvitamin D-1-hydroxylase activity. J. Clin. Endocrinol. Metab. 54:638643.

2. Insogna, K. L., A. E. Broadus, and J. M. Gertner. 1983. Impaired phosphorus conservation and 1,25-dihydroxyvitamin $D$ generation during phosphorus deprivation in familial hypophosphatemic rickets. J. Clin. Invest. 71:1562-1569.

3. Meyer, R. A., Jr., R. W. Gray, and M. H. Meyer. 1980. Abnormal vitamin D metabolism in the X-linked hypophosphatemic mouse. Endocrinology. 107:1577-1581.

4. Lobaugh, B., and M. K. Drezner. 1983. Abnormal regulation of renal 25-hydroxyvitamin D-1 $\alpha$-hydroxylase activity in the X-linked hypophosphatemic mouse. J. Clin. Invest. 71:400-403.

5. Tenenhouse, H. 1983. Abnormal renal mitochondrial 25-hydroxyvitamin $D_{3}-1 \alpha$-hydroxylase activity in the vitamin $D$ and calcium deficient X-linked Hyp-mouse. Endocrinology. 113:816-818.

6. Fukase, M., L. V. Avioli, S. J. Birge, and L. R. Chase. 1984. Abnormal regulation of 25 -hydroxyvitamin $\mathrm{D}-1 \alpha$-hydroxylase activity by calcium and calcitonin in renal cortex from hypophosphatemic (Hyp) mice. Endocrinology. 114:1203-1207.

7. Tenenhouse, H. 1984. Investigation of the mechanism for abnormal renal 25-hydroxyvitamin $D_{3}-1 \alpha$-hydroxylase activity in the X-linked Hyp mouse. Endocrinology. 115:634-639.

8. Lobaugh, B., and M. K. Drezner. 1983. Measurement of 25-hydroxyvitamin D-1 $\alpha$-hydroxylase activity in mammalian kidney. Anal. Biochem. 129:416-424.

9. Tenenhouse, H. S., and C. R. Scriver. 1979. Renal adaptation to phosphate deprivation in the Hyp-mouse with X-linked hypophosphatemia. Can. J. Biochem. 57:938-944.

10. Meyer, R. A., Jr., R. W. Gray, B. A. Roos, and G. M. Kiebzak. 1982. Increased plasma 1,25-dihydroxyvitamin $\mathrm{D}$ after low calcium challenge in X-linked hypophosphatemic mice. Endocrinology. 111:174 177.

11. Haddad, J. G., and S. J. Birge. 1975. Widespread, specific binding of 25-hydroxycholecalciferol in rat tissues. J. Biol. Chem. 250:299-303.

12. Botham, K. M., Y. Tanaka, and H. F. Deluca. 1974. 25-hydroxyvitamin $D_{3}$-1-hydroxylase inhibition in vitro by rat and pig tissues. Biochemistry. 13:4961-4966.

13. Kream, B. E., R. D. Reynolds, J. C. Knutson, J. A. Eisman, and H. F. DeLuca. 1974. Intestinal cytosol binders of 1,25-dihydroxyvitamin $D_{3}$ and 25-hydroxyvitamin $D_{3}$. Arch. Biochem. Biophys. 176:779-787.

14. Van Baelen, H., R. Bonillon, and P. DeMoor. 1977. Binding of 25-hydroxycholecalciferol in tissues. J. Biol. Chem. 252:2515-2518.

15. Cloix, J. F., M. Bachelet, A. Ulmann, and J. L. Funck-Brentano. 1978. 25-hydroxycholecalciferol-binding protein: partial purification from rat duodenal mucosal cells. Biochem. Biophys. Res. Comm. 83:14561463.

16. Cooke, N. E., J. Walgate, and J. G. Haddad. 1979. Human serum binding protein for vitamin D and its metabolites. I. Physiochemical and immunological identification in human tissues. J. Biol. Chem. 254: 5958-5964.

17. Cooke, N. E., J. Walgate, and J. G. Haddad. 1979. Human serum binding protein for vitamin $\mathrm{D}$ and its metabolites. II. Specific, high affinity association with a protein in nucleated tissue. J. Biol. Chem. 254:59655971.

18. Van Baelen, H., R. Bonillon, and P. DeMoor. 1980. Vitamin Dbinding protein (Gc-globulin) binds actin. J. Biol. Chem. 255:2270-2272.

19. Lyles, K. W., A. G. Clark, and M. K. Drezner. 1982. Serum 1,25-dihydroxyvitamin D levels in subjects with X-linked hypophosphatemic rickets and osteomalacia. Calcif. Tissue Int. 34:125-130.

20. Dryer, R. L., A. R. Tammes, and J. I. Routh. 1957. The determination of phosphorous and phosphatase with $N$-phenyl-p-phenylenediamine. J. Biol. Chem. 225:177-183.

21. Neter, J., and W. Wasserman. 1974. Applied Linear Statistical Models. R. D. Irwin, Inc., Hanswerd, IL.

22. Scriver, C. R., T. M. Reade, H. F. DeLuca, and A. J. Hamstra. 1978. Serum 1,25-dihydroxyvitamin $D$ levels in normal subjects and in patients with hereditary rickets or bone disease. N. Engl. J. Med. 299: 976-979.

23. Chesney, R. W., R. B. Mazess, P. Rose, A. J. Hamstra, and H. F. DeLuca. 1980. Supranormal 25-hydroxyvitamin D and subnormal 1,25-dihydroxyvitamin D: their role in X-linked hypophosphatemic rickets. Am. J. Dis. Child. 134:140-143.

24. Fukase, M., S. J. Birge, L. Rifas, L. V. Avioli, and L. R. Chase. 1982. Regulation of 25-hydroxyvitamin $D_{3} 1$-hydroxylase in serum free monolayer culture of mouse kidney. Endocrinology. 110:1073-1075.

25. Vieth, R., and D. Fraser. 1979. Kinetic behavior of 25-hydroxy- 
vitamin D-1-hydroxylase and -24-hydroxylase in rat kidney mitochondria. J. Biol. Chem. 254:12455-12460.

26. Tanaka, Y., and H. F. DeLuca. 1981. Measurement of mammalian 25-hydroxyvitamin $\mathrm{D}_{3} 24 \mathrm{R}$ - and $1 \alpha$-hydroxylase. Proc. Natl. Acad. Sci. 78:196-199.

27. Garabedian, M., M. F. Holick, H. F. DeLuca, and I. T. Boyle. 1972. Control of 25-hydroxycholecalciferol metabolism by parathyroid glands. Proc. Natl. Acad. Sci. 69:1673-1676.

28. Henry, H. 1979. Regulation of the hydroxylation of 25-hydroxyvitamin $\mathrm{D}_{3}$ in vivo in primary cultures of chick kidney cells. J. Biol. Chem. 254:2722-2729.

29. Baksi, S. N., and A. D. Kenny. 1978. Acute effect of estradiol on the renal vitamin D hydroxylases in Japanese quail. Biochem. Pharmacol. 27:2765-2768.

30. Eicher, E. M., J. L. Southard, C. R. Scriver, and F. H. Glorieux 1976. Hypophosphatemia: mouse model for human familial hypophosphatemic (vitamin D-resistant) rickets. Proc. Natl. Acad. Sci. USA. 73 4667-4671.

31. Cogwill, L. D., S. Goldfarb, K. Lou, E. Slatopolsky, and Z. S.
Agus. 1979. Evidence for an intrinsic renal tubular defect in mice with genetic hypophosphatemic rickets. J. Clin. Invest. 63:1203-1210.

32. Kiebzak, G. H., B. A. Roos, and R. A. Meyer, Jr. 1982. Secondary hyperparathyroidism in X-linked hypophosphatemic mice. Endocrinology. 111:650-652.

33. Posillico, J. T., B. Lobaugh, L. H. Muhlbaier, and M. K. Drezner. 1985. Abnormal parathyroid function in the $\mathrm{X}$-linked hypophosphatemic mouse. Calcif. Tissue Int. 37:418-422.

34. Obie, J. F., and C. W. Cooper. 1979. Loss of calcemic effects of calcitonin and parathyroid hormone infused continuously into rats using the Alzet osmotic minipump. J. Pharmacol. Exp. Ther. 209:422-428.

35. Tam, C. S., G. Jones, and J. N. M. Heersche. 1981. The effect of vitamin $\mathrm{D}$ restriction and repletion on bone apposition in the rat and its dependence on parathyroid hormone. Endocrinology. 109:1448-1453.

36. Podbesek, R., C. Edouard, P. J. Meunier, J. A. Parsons, J. Reeve, R. W. Stevenson, and J. M. Zanelli. 1983. Effects of two treatment regimes with synthetic human parathyroid hormone fragment on bone formation and the tissue balance of trabecular bone in greyhounds. Endocrinology 112:1000-1006. 